\title{
Evaluation of in vitro Antibacterial Activity of Phage Lysate against Microbial Pathogen Isolated from Septic Wounds
}

\author{
Sanjay Shukla*, A. Nayak, R. K. Sharma, P. C. Shukla and R. V. Singh \\ Department of Veterinary Microbiology, College of Veterinary Science \& A.H., Nanaji \\ Deshmukh Veterinary Science University, Jabalpur, Madhya Pradesh, India \\ *Corresponding author
}

\section{A B S T R A C T}

\begin{tabular}{l} 
Key w or d s \\
$\begin{array}{l}\text { In vitro, S. aureus } \\
\text { Antibacterial } \\
\text { activity, Phage } \\
\text { lysate, Antibiotic } \\
\text { resistance }\end{array}$ \\
\hline Article Info \\
$\begin{array}{l}\text { Accepted: } \\
\text { 10 September } 2020 \\
\text { Available Online: } \\
\text { 10 October } 2020\end{array}$ \\
\hline
\end{tabular}

In present study, we had isolated the bacteriophages from sewage material of various livestock farms, NDVSU, Jabalpur Madhya Pradesh. The recovered bacteriophages subjected for the identification with electron microscopy. The isolated bacteriophages had shown icosahedral symmetry. Phage had hexagonal head with the size of $52.20 \mathrm{~nm}$ in diameter and long tail of $109 \mathrm{~nm}$. They were classified as a member of the Myoviridae family under the order of Caudovirale. These recovered bacteriophages were subjected to spottest to know the antibacterial activity against bacterial pathogens. All the recovered phage lysate showed the antibacterial activity specifically against the Staphylococcus aureus isolated from chronic septic wounds. These isolates of bacteriophage had limited host range due to their nature to infect the specific host. There was few isolates (ØVS4 ØVS5 and ØVS9) of bacteriophages were showing the lytic activity against the other microbial organism like Bacillus spp and E. coli. ØVS4, ØVS5 and ØVS9 three isolates of bacteriophage had broad host range. In vitro antibacterial activity of phage lysates can be used as a potential therapy against multiple drug resistant pathogens in the current era of antibiotic resistance crisis.

\section{Introduction}

Bacteriophages are natural predators of bacteria and found ubiquitously, these organisms are estimated to be present at numbers equivalent to a trillion per grain of sand on earth (Keen, 2015). Bacteriophages that infect $S$. aureus, are of the order Caudovirales (Xia and Wolz, 2014). They are DNA viruses of Siphoviridae and Myoviridae families (Ackermann, 2009). They are obligate intracellular parasites requiring specific bacteria as host cell for their replication (Carlton, 1999). Phages are most widely distributed and diverse entities in the biosphere and ubiquitously present, which can be found in all reservoirs populated by bacterial hosts, such as soil and intestine of animals (McGrath and van Sinderen, 2007). Bacteriophages were co-discovered by Felix d'Herelle and Frederick Twort.

The current resurgence of interest is persisting in light of the growing urgency of the antimicrobial resistance (AMR) crisis, which predicts that AMR will be the leading cause of death by 2050, causing 10 million global deaths per year (O'Neill, 2016). When 
antibiotic resistance first emerged, novel antibiotics to treat these bacteria were developed. Bacteriophages are potential antibacterial therapeutic agents against such multiple drug resistant pathogens (Burrowes et al., 2011). Also, unlike chemical therapeutic agents, phages are not susceptible to the onset of bacterial resistance because they have the ability to evolve with their host (Sulakvelidze and Kutter, 2005).

The natural ability of pathogens to develop resistance is not only a threat to animal health but also leads to accumulation of antibiotic residues in livestock products. Consumption of these livestock products leads hazardous threat for human population. In vitro antibacterial activity of recovered phage lysates can be used as a potential therapeutic alternate against multiple drug resistant pathogens in the current era of antibiotic resistance crisis.

\section{Materials and Methods}

\section{Culture media used during study}

Commercially available ready to use dehydrated media (Hi-Media Laboratories Limited) were used for the preparation of culture media. Instructions given by manufacturers for reconstitution of respective media were followed. The fresh media were prepared, tested for sterility and stored at refrigeration temperature until use.

Following laboratory media were used in the present investigation:

Basal agar (tryptone broth with 1.5\% agar) Mannitol salt agar

Muller-Hinton agar

Nutrient agar

Nutrient broth

Soft agar (tryptone broth with $0.7 \%$ agar)

Tryptone soya broth
Sewage samples for bacteriophage isolation

Sewage samples for bacteriophage isolation were collected from livestock farms (cattle, buffalo, pig and goat), N.D.V.S.U., Jabalpur (M.P.). Sewage material consisted of various body excretions from different species of animal's viz. cattle, buffalo, goat and pig. One hundred fifty samples were collected in sterile tubes from various collection tanks and storage pits of integrated livestock farm complex, Adhartal, N.D.V.S.U., Jabalpur (M.P.).

\section{Isolation of bacteriophage from sewage samples}

Staphylococcus aureus (ATCC 25923) was the host bacterium used for isolation of bacteriophage from sewage samples. Sewage samples isolation were for bacteriophage collected from livestock farms (cattle, buffalo, pig and goat), N.D.V.S.U., Jabalpur (M.P.). Isolation of bacteriophages was done by soft agar overlay method as described by Synnot et al., (2009) with slight modification. The recovered phage isolates were characterized and studied for in vitro antibacterial activity

\section{In-vitro assessment of antimicrobial activity of phage lysate}

Bacteriophage isolates recovered from the sewage samples of various livestock farms were tested to know the antibacterial activity. The bacterial lawn of $S$. aureus was prepared by flooding agar plate with $2 \mathrm{ml}$ trypton soya broth culture. Bacteriophage lysate was spotted onto a lawn, then the plates were incubated at $37^{\circ} \mathrm{C}$ and formation of plaques was observed at various time intervals at 6 , 12, 18 and $24 \mathrm{~h}$. Similar approach was adopted by Iwano et al., (2018).

\section{Results and Discussion}

Pus samples were collected from the chronic septic wounds infections of animlas. These 
collected samples were subjected for the isolation and identification of microbial pathogens associated with wounds. All the chronic septic wounds were infected with multiple pathogens like S. aureus, E coli, Bacillus spp and Pseudomonas spp.

Result of bacterial isolation of chronic septic wounds infections indicated that the most of the septic wounds were infected with multiple bacterial pathogens in which Staphylococcus spp, Escherichia spp, Pseudomonas spp and Bacillus spp were predominantly associated. Our findings were in confirmation with the findings of Vinodkumar et al., (2008) and Heo et al., (2009).

Further these bacterial isolates were subjected for spot test. The bacterial lawn was prepared by flooding agar plate with $2 \mathrm{ml}$ broth culture. Phage lysate was spotted onto a lawn, then the plates were incubated at $37^{\circ} \mathrm{C}$ for $24 \mathrm{~h}$ and formation of plaques was observed at various time intervals at $6,12,18$ and $24 \mathrm{~h}$.

Result of present study revealed that all the isolates of bacteriophage were showing the good antibacterial activity against the all $S$. aureus isolates from chronic septic wounds. They are very having narrow host range specifically infecting to $S$. aureus. There were few isolates of phage especially ØVS4, ØVS5 and ØVS9 were showing the antibacterial activity against the other microbial organism like Bacillusspp and E. coli. Therefore these three isolates of phage out of all twenty seven had shown broad host range. Our findings were in support of findings of Melo et al., (2014) and Sarhan et al., (2016) they find out that the good infectivity shown by this bacteriophage as well as its high lytic spectrum suggested that it might be a good candidate for therapeutic studies. Lehman et al., (2019) observed that $95 \%$ isolates were lysed by the bacteriophage in in vitro activity. In conclusions the bacteriophages isolated from sewage material were assessed for in vitro antibacterial activity. All the 27 recovered phages isolates were showing the antibacterial activity against $S$. aureus isolated from the chronic septic wounds. They are very having narrow host range specifically infecting to $S$. aureus. ØVS4, ØVS5 and ØVS9 of bacteriophages were showing the lytic activity against the other microbial organism like Bacillus spp and E. coli. Therefore these three isolates of ØVS4, ØVS5 and ØVS9 had broad host range as compare to others isolates. In vitro phage lysate had shown good antibacterial activity against $S$. aureus. In vitro antibacterial activity of phage lysates exploring the utility of bacteriophage as a potential alternate of antibiotic against multiple drug resistant pathogens which can be helpful to overcome the crisis of antibiotic resistance.

\section{Acknowledgment}

I am highly obliged and grateful to Dr. R.K. Sharma, Dean, College Veterinary Sc. \& AH., Jabalpur for his encouraging advice during my entire course and research work. I am also thankful to Mr. Vijay Kumar, IISER, Bhopal, for providing me the facility of electron microscopy to identify the phage isolates.

\section{References}

Ackermann, H.W., 2009. Phage classification and characterization. In: Clokie M.R., Kropinski A.M. (eds) Bacteriophages. Methods in Molecular Biology ${ }^{\mathrm{TM}}$, vol 501. Humana Press, Pp, 15-17.

Burrowes, B., Harper D.R., Anderson J., McConville M. and Enright, M.C. 2011. Bacteriophage therapy: potential uses in the control of antibiotic resistant pathogens. Expert Review of Anti Infective Therapy.9(9): 775-785.

Carlton, R.M., 1999. Phage therapy: past history and future prospects. Archives Immunology et. Therapiae Experimentalis. 47: 267-274. 
D’Herelle, F., 1931.Bacteriophage as a treatment in acute medical and surgical Infections. Bulletin of the New York Academy of Medicine.7: 329-348.

Heo, Y.J., Lee Y.R., Jung H.H., Lee J., Ko G. and Cho, Y.H. 2009. Antibacterial efficacy of phages against $P$. aeruginosa infections in mice and D. melanogaster. Antimicrobial Agents and Chemotherapy.53(6): 24692474.

Iwano, H., Yusuke Inoue I.D., Takasago T., Kobayashi H., Furusawa T., Taniguchi K., Fujiki J., Yokota H., Usui M., Tanji Y., Hagiwara K., Higuchi H. and Tamura, Y. 2018. Bacteriophage $\Phi S A 012$ has a broad host range against $S$. aureus and effective lytic capacity in a mouse mastitis model. Biology. 7(8): 1-13.

Keen, E.C., 2015. A century of phage research: Bacteriophages and the shaping of modern biology. Bioessays.37: 6-9.

Lehman, S.M., Mearns G., Rankin D., Cole R.A., Smrekar F., Branston S.D. and Morales, S. 2019. Design and preclinical development of a phage product for the treatment of antibiotic-resistant $S$. aureus infections.Viruses.11(88): 2-16.

McGrath, S., and van Sinderen, D. 2007. Bacteriophage: Genetics and Molecular Biology (1st ed.). Caister Academic Press. Irelend. Pp 343-344.

Melo, L.D.R., Sillankorva S., Ackermann H.W., Kropinski A.M., Azeredo J. and Cerca, N. 2014. Isolation and characterization of a new $S$. epidermidis broad-spectrum phage. Journal of General Virology.95: 506-515.

O’Neill, J., 2016. Tackling drug resistance infections globally: Final report and recommendations. Review on Antimicrobial Resistance.5: 2.

Sarhan, R., Orooba-Ibrahim M.S. and Salih, S.I. 2016. In vitro evaluation of isolated Staphylococcal-bacteriophage in killing MR S. aureus. Kufa Journal for Veterinary and Medical Sciences.7(4): 16-18.

Sulakvelidze, A. and Kutter, E. 2005. Phage therapy: An attractive option for dealing with antibiotic resistant bacterial infections. Elsevier.10(13): 876-877.

Synnott, A.J., Kuang Y., Kurimoto M., Yamamichi K., Iwano H. and Tanji, Y. 2009. Isolation from sewage influent and characterization of novel $S$. aureus phages with wide host ranges and potent lytic capabilities. Applied Environmental Microbiology. 75(13): 4483-4490.

Vinodkumar, C.S., Kalsurmath S. and Neelagund, Y.F. 2008.Utility of lytic bacteriophage in the treatment of multidrug-resistant $P$. aeruginosa septicemia in mice.Indian Journal of Pathology and Microbiology.51(3): 360-366.

Xia, G., and Wolz, C. 2014. Phages of S. aureus and their impact on host evolution. Infection, Genetics and Evolution.21: 593-601.

\section{How to cite this article:}

Sanjay Shukla, A. Nayak, R. K. Sharma, P. C. Shukla and Singh, R. V. 2020. Evaluation of in vitro Antibacterial Activity of Phage Lysate against Microbial Pathogen Isolated from Septic Wounds. Int.J.Curr.Microbiol.App.Sci. 9(10): 1214-1217. doi: https://doi.org/10.20546/ijcmas.2020.910.145 